\title{
Engaging tour operators in sustainable tourism: the Dutch professional association's approach
}

\author{
J. van Wijk \& F. G. A. de Bakker \\ Vrije Universiteit, Amsterdam
}

\begin{abstract}
Different initiatives have been proposed to enhance the level of sustainability in the tourism industry. In the Netherlands, the professional association of tour operators has developed and implemented a product-oriented environmental management system among its members. Contrary to most initiatives in the tourism industry, this scheme is mandatory. This case therefore provides an interesting account of how a professional association attempts to engage tour operators in a change process towards sustainability. Adopting an institutional change perspective, we distinguish two approaches to get a targeted population involved in processes of change: (a) treating them as objects who have no choice other than to follow up to the expectations exerted upon them; or (b) as subjects who are able to influence those expectations. By analyzing the content of two periodicals the Dutch association has published over the last decade, we explore whether the Dutch tour operators were treated as objects or as subjects in this trajectory of change. Our results show that the dichotomy between object and subject masks a wide variety of how professional associations may approach their members, while it also illustrates how these approaches can change over time. We conclude with recommendations for professional associations who are planning to move their industry branch towards sustainable tourism.

Keywords: institutional change, professional associations, tour operators, environmental certificates.
\end{abstract}

\section{Introduction}

Tour operators hold an intermediary position within the tourism supply chain. As they link different tourism services into pre-packaged holidays, they are considered agents for sustainable tourism [3, 9, 13]. For instance, they may 
include certified services in their packages, educate their customers and staff on responsible behaviour and stimulate destination management. Professional associations can play an important role in enthusing individual tour operators for sustainable tourism management. The Dutch Association of Tour Operators (VRO/ANVR) has developed a product-oriented environmental management scheme (POEMS) to assist its members in this process. POEM can be defined as "organizing and operating a firm in such a way that improving the environmental performance of its products becomes an integrated part of operations and strategy" [6, p. 56]. Although all tour operators associated with VRO/ANVR have adopted this obligatory scheme by now, the initial scheme was revised at several occasions, due to member resistance and objections [21, 22]. Studying this specific case in greater detail provides an interesting account of how a professional association has approached the potential adopters of its desired change process and how this has influenced the change process [11].

By analyzing the content of two periodicals VRO/ANVR has published over the last decade, we explore the way this professional association has approached tour operators over time to get its scheme accepted by its members. There are three reasons why this case is of specific relevance for tourism management literature. First, there are few organized attempts within this industry aimed at enhancing the level of sustainability of tour operating firms [18]. Moreover, most initiatives in the field of sustainable tourism are of a voluntary nature [23], whereas the Dutch scheme is mandatory. Second, professional associations have received little scholarly attention in tourism studies in general [20] and in studies of the tour operating industry in particular. Research in the hospitality industry shows that hotel trade associations are key actors in guarding corporate social responsible behaviour $[5,15]$, thereby supporting the notion of professional associations as key constituents in institutional change [10]. Third, our understanding of the mechanisms behind the emergence and spread of corporate norms on sustainable tourism is limited. Most studies focus on the outcomes of certification programs $[16,18]$, while less attention is paid to the question how those programs come about. This is of particular relevance as eco-labels, hallmarks and codes of conduct are increasingly put forward to regulate this industry [8].

This article is structured as follows. First, we briefly outline a theoretical framework of the process of institutionalization, emphasizing an agency perspective. Second, we introduce the main sources we used to analyze how VRO/ANVR has attempted to move its members closer towards sustainable tourism. Then we present our empirical results, leading us to make inferences about the way VRO/ANVR approached its members and the consequences for the process of institutionalization. This results in some concluding remarks for professional associations who are planning to move their industry branch towards sustainable tourism.

\section{Institutional change, agents and targets}

The process towards sustainable tourism as stimulated by the professional association can be seen as a process of institutional change: the current 
institutional context is challenged and modified in order to establish a more sustainable way of doing business among tour operators. To understand the processes through which professional associations try to evoke such a change, it is useful to consider how agents approach the targets of change.

\subsection{Institutional change}

Eco-labels, hallmarks and certificates all can be viewed as 'institutions' as they relate to particular norms and values on how to behave as a socially responsible organization that takes calls for sustainable tourism seriously. When all organizations within an industry behave in line with these norms and values, a process of institutionalization has taken place: "a social process by which individuals come to accept a shared definition of social reality - a conception whose validity is seen as independent of the actor's own views or actions but is taken for granted as defining the 'ways things are' and/or 'ways things are to be done" [17, p. 496]. Within this process, two temporal characteristics can be identified: the pace of institutionalization, being the time required for an innovation to spread throughout a population, and the stability of institutionalization which involves how long an innovation remains perceived as 'taken-for-granted' [11]. The role of agents in shaping the process of institutional change is increasingly studied. These agents are regularly referred to as institutional entrepreneurs [2,7]: individuals or organized actors who strive for the creation of new institutions or the modification of existing ones to suit their own interests [12]. These particular actors thus operate as change agents who attempt to motivate others to join and support their desired change. Although professional associations are generally not renowned for their innovativeness, they may act as change agents [10].

\subsection{Professional associations as agents}

Professional associations perform a number of tasks for the members they represent such as developing product/process standards; presenting their members' professional identity and their interests externally; and monitoring trends within business, legislation and society in general [20, 10]. Within tourism industry, some professional associations are actively involved in promoting sustainable tourism. For instance, the U.S. National Ski Areas Association developed a 'Sustainable Slopes Program', aimed at stimulating environmentally sound behaviour by ski resorts [16], and had already taken similar initiatives before [19]. The Chamber of Tourism in Costa Rica also established a certification scheme for its associated hotels [15]. As a membership-based organization, professional associations are in a difficult position. They need to manage the diversity of members' interests. While some firms within an industry are eager to become frontrunners in corporate social behaviour, the majority of firms will not be keen on such measures. Indeed, in Costa Rica less than ten percent of the hotels eventually enrolled in the certification program [15]. How to engage associated members in the process of change hence is of strategic relevance for professional associations. 


\subsection{Targets as objects and as subjects}

Lawrence et al. [11] contend that actors who strive for change may approach their targeted audience in two ways: as objects or as subjects. If the target is treated as an object in the process, it is seen as "an actor incapable of choice or whose choice was irrelevant to the effective exercise of power" [11, p. 631]. When treated as a subject, a target has agency: the actor is able to choose and thus to influence the change process in the making. Lawrence et al. argue that the way an actor approaches his target audience has consequences for the temporal dynamics of the institutionalization process. Allowing agency to targets has the advantage that these actors may internalize what is expected from them as the natural way of doing things, resulting in a high stability of the new institution. A disadvantage of a subject approach is that the targets may question the change that is expected from them, leading to endless negotiations and hence a low pace of institutionalization. When treating targets as objects, the pace of institutionalization is likely to be high, as targets are not involved in the decision-making process on how to solve the perceived problematic situation. However, the intrinsic motivation to maintain the new situation then is virtually non-existent, resulting in a low stability of the institution.

\subsection{Research question}

In our case study of institutional change, the professional association of tour operators develops a potential institution: the obligatory environmental management scheme. With this scheme the association aims to make norms on sustainable tourism an integrated part of the daily business of tour operators. From the brief discussion of theoretical insights, we can derive our detailed research question: How does the professional association VRO/ANVR approach its associated tour operators in developing and spreading POEMS among its members and how does this influence the process of institutionalization of POEMS?

\section{Methods}

\subsection{Research site}

The field under study is the Dutch tour operating industry. Out of 34,6 million holidays spent by the Dutch in 2003, $44 \%$ was organized by the travel industry [14]. Estimates of the number of tour operators range from 415 in 1993 to 665 in 2003 [4]. In 2003 about $25 \%$ of the Dutch tour operators were members of the Association of ANVR Tour Operators (VRO/ANVR), representing 80-90\% of the industry turnover (personal communication VRO/ANVR). VRO/ANVR is a member of the Dutch Federation of Travel Businesses (ANVR), which was founded as a professional association in 1966 and which has been an employers' federation since 1994. An important reason for tour operators to join VRO/ANVR is that the association allows them to make use of its widely recognized logo, which serves as a quality hallmark for consumers. 


\subsection{Data sources}

We started our case study [24] by interviewing 22 individuals to improve our historical understanding of the change process towards sustainable tourism in the Dutch tour operating industry. All respondents were or still are involved in this process. From our interviews we learned that VRO/ANVR has played a crucial role in instigating change by developing the mandatory POEMS. An additional, pragmatic reason to focus our case study on this organization is that membership-based organizations generally produce lots of texts to communicate with their members, providing us with rich longitudinal data sources. Indeed, we collected all articles on sustainable tourism published in the two periodicals that the association produced in the 10-year period from 1996 to 2005, a paper-based magazine (called ATLAS) and an electronic newsletter. In 2001 no texts on sustainable tourism were produced. From both periodicals we selected text fragments in which VRO/ANVR reported on policies and activities related to sustainable tourism, resulting in a database containing 666 records.

\subsection{Data-analysis}

To examine how VRO/ANVR approached its members on the issue of sustainable tourism, we used a modified form of content analysis. The first author coded whether the targets were treated as object or as subject in each record, looking at the activities VRO/ANVR deployed to engage its members in the institutional change process. For instance, an invitation for active member participation in policy-making would be coded as 'subject', whereas the mere informing of members of a new policy plan would be coded as 'object'. The text records have thus been read at two levels: (a) as a chronological report of actions taken by VRO/ANVR to develop and promote POEMS among its members, and (b) as discursive statements on those actions expressing how the professional association approached its members to stimulate institutionalization of POEMS. We finally made inferences about the way VRO/ANVR approached its members and how this influenced the process of institutionalization.

\section{Case study}

Due to space limitations, in this section only a brief overview of the entire case study is presented. During the 1980s, ANVR is increasingly pressurized to address issues relating to sustainable tourism. Although several collective measures indeed are taken, it is not until the end of the 1990s that more farreaching measures are proposed. In 1995 an internal Study Group on Sustainable Tourism is established, including several major tour operators and a few small ones. This Group publishes a policy document in August 1995 in which measures are proposed to enhance the level of sustainability in the industry. From 1995 onwards, VRO/ANVR together with the Study Group tries to implement these measures.

In order to structurally and systematically embed these collective measures at the individual firm level, the association develops a product-oriented 
environmental management scheme (POEMS) between 1998 and 2000. VRO/ANVR reports frequently on the POEMS project in its periodicals. A consultancy firm, the Study Group and several pilot firms participate in this project. Next to the POEMS project, VRO/ANVR drafts a second policy plan on sustainable tourism in 1998. At the annual meeting of December 2000 the VRO/ANVR tour operators agree to acquire a POEMS certificate before April 2003 as part of their membership.

However, once the agreed date of compliance approaches it becomes clear that the support for POEMS is rather weak. Therefore, early 2002, VRO/ANVR starts sending electronic 'POEMS-Bulletins' to its members and organises two general meetings on the subject. These sessions not only inform tour operators on POEMS, but also make them realize what they actually agreed to when they accepted the scheme as a membership criterion in 2000 [22]. In response to the increasing opposition, VRO/ANVR organises information exchange sessions for specific groups of tour operators. Yet, resistance mounts and VRO/ANVR has to postpone the deadline for compliance and to abandon several requirements of the scheme. The first POEMS Certificates are awarded in June 2003, but it takes another year before all tour operators obtain their certificate. It is estimated that five tour operators cancelled their membership because of the POEMS requirements [22].

Recent research on the implementation of the POEMS Certificate indicates that $20-30 \%$ of the industry is loyal to the POEMS philosophy [22]. Being inspired by the number of potential frontrunners in the industry, VRO/ANVR has continued its work on sustainable tourism with this smaller group of tour operators over the past few years. In addition, the Dutch scheme has become recognized internationally and is put forward as a 'best practice' in an international project supported by the European Commission.

\section{Discussion}

\subsection{Engagement in sustainable tourism (prior to 1998)}

Although professional associations generally follow the developments within their membership base [10], the association we studied also adhered to actors from outside the field that called for change, such as policy makers and interest groups. It set up an internal Study Group, including a selected group of tour operators. Aldrich [1] pointed out that a small elite is often heavily involved in the policy making of professional associations. In our case study this can also be observed as the internal Study Group mainly consisted of representatives of the large tour operators in the Netherlands. In order to get its members along in the envisaged change process, VRO/ANVR regularly informed its members through annual reports, discussed related issues at annual meetings and provided discursive space to its proponents in their periodicals. Figure 1 shows that tour operators initially were mainly approached as an object. For instance, the selection of sustainable tourism as a topic of relevance for VRO/ANVR is presented as a fait a compli. Yet, calls for participation are already visible early 
on in the process, indicating a subject approach. These include invitations to provide input for plans, or to vote on new proposals during annual meetings. Still, most of the early records indicate an object approach.

\subsection{Introducing POEMS (1998-2002)}

From 1998 onwards, VRO/ANVR started to work on the introduction of POEMS. This scheme not only fitted in with the professional association's desire to promote sustainable tourism but later on was adapted to fit in with the rising discourse on corporate social responsibility as well. The POEM scheme was strongly promoted as a membership criterion. Doing so suggest the application of an object approach, as members' choice was irrelevant to the effective exercise of this measure. Nevertheless, some room for agency also was visible in the texts: when reporting on all sustainable tourism activities going on, members were invited to join the internal Study Group in order "to speed up and maintain the pace of change as sustainable tourism is an important and interesting part of ANVR's policies" (ATLAS, October 1998). In addition, a few firms had been engaged in testing POEMS. Those pilot-firms reported on their experiences in the magazine. At the annual conference in 1999, POEMS was presented as part of the industry's answer to the increasing calls for corporate social responsibility. Again, members were invited to actively participate in the change process during this annual meeting.

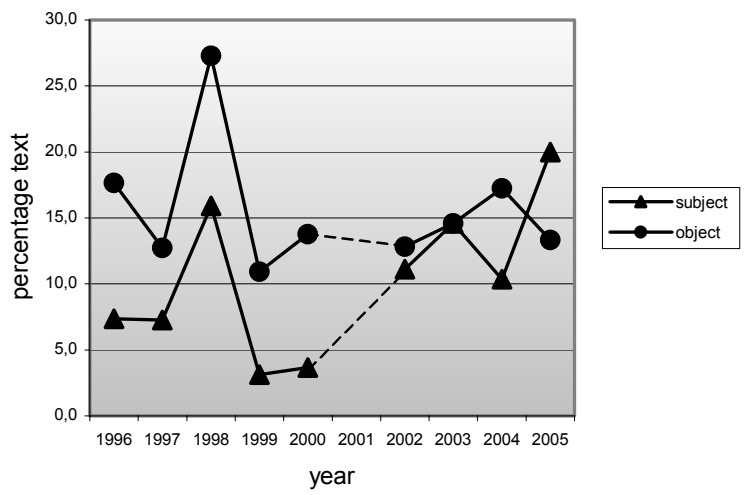

Figure 1: Percentage of text per approach per year.

\subsection{Implementing POEMS (2002-2005)}

Once the decision on introducing POEMS needs to be effectuated, it gradually became clear that not all members were willing to go along in the plans as proposed. ANVR/VRO was forced to change its approach into a subject approach and to grant more agency to its membership base. At the same time, VRO/ANVR's commitment to the issue of sustainable tourism was increasingly recognized by external national and international actors. Given the commitments 
already made, VRO/ANVR could not pull back from POEMS but was forced to withdraw several requirements of the scheme and to postpone the fixed date for its full introduction. Looking back at the data, this is quite a logical development. In order to develop corporate norms on sustainable tourism, VRO/ANVR cooperated with a subset of its membership base. Once those norms were embodied in POEMS, the association was able to start promoting these norms among its wider population. This was facilitated by the requirement of POEMS to appoint an environmental coordinator within every firm. Information on POEMS therefore could now be spread in a focused manner. The spreading of this information, together with the nearing deadline for implementation, gave rise to specific questions from members, leading VRO/ANVR to establish different POEMS meetings for different subsections of its membership base. The gradual increase in member consultation eventually lead to a fuller awareness of the implications of the plans for the members and therefore a more active involvement. Members finally started to use the agency they were offered, presumably more so than anticipated by the professional association. This led to several adjustments of the scheme. Figure 1 also shows an increase in the treatment of tour operators as subject in the texts as the implementation of POEMS comes nearer.

\section{Conclusion}

In this paper we examined how the professional association VRO/ANVR approached its member tour operators in developing and spreading POEMS among them. Our case study supports the notion that the way an agent approaches its target population has consequences for the temporal dynamics of the process of institutionalization [11]. The tour operators that participated in the internal Study Group on Sustainable Tourism were involved as co-producers of the change process towards sustainable tourism. They were treated as subjects and hence internalized the necessity for change. As a representative of VRO/ANVR noted: "what already was on the Study Group members' minds was not yet on the tour operators' minds" [22, p. 23]. Several firms that have been part of the Study Group now belong to the industry's frontrunners in sustainability issues. The members that did not participate in this Group were mainly approached as objects. They were informed on the developments through various means (periodicals, annual meetings, conferences). Still, VRO/ANVR offered these members several opportunities to comment on those developments. Notably, at the annual meeting of December 2000 tour operators were invited to formally vote on the introduction of POEMS. As the majority of tour operators did not deploy this agency during the development of POEMS, the object approach enabled VRO/ANVR to decide on the trajectory of change as strived for. The object-approach was challenged when the date of compliance for POEMS came closer. Confronted with norms and values that were new to them, tour operators called the feasibility of POEMS into question. In order to overcome the increased opposition, VRO/ANVR switched more towards a subject approach, allowing members to influence the change process in the 
making. This slowed down the intended change process as VRO/ANVR engaged in negotiations on the requirements of POEMS. While tour operators learned more about the need for change and what was expected from them through the specific bulletins and meetings, the 'object-treated-tour operators' have not yet fully internalized the importance of POEMS. POEMS has thus not yet become taken for granted within their firms, resulting in a low stability of POEMS in the industry [22].

To conclude, the object-approach by VRO/ANVR had the advantage that POEMS was accepted as a membership criterion. The subject-approach enabled a small group of (large) tour operators to internalize the issue of sustainable tourism and become frontrunners of the industry, thereby pressuring the other firms to move forward. By extending the subject-approach to its wider membership base later on, VRO/ANVR managed to keep the other tour operators on board. The explicit, though solicited, consent of members to make POEMS a membership criterion served as a big stick in this approach: the requirements of POEMS were negotiable, while the introduction of POEMS was yet decided on collectively. VRO/ANVR might have extended its subject approach earlier in the process, involving representatives from the different subsections. These representatives then again could have functioned as change agents within their subsection. However it is questionable if VRO/ANVR would have been able to set up such a group as tour operators might not have been interested to get involved because of their constantly perceived lack of time and resources [22]. Hence, if a professional association, or any other institutional entrepreneur, aims to evoke institutional change, it should take into account the different subsets within a population. A smart mixture of approaches at different stages in the change process is crucial for stimulating change through frontrunners without losing the remaining participants.

\section{References}

[1] Aldrich, H. E. 1999. Organizations evolving. Thousand Oaks, Ca: Sage.

[2] Beckert, J. 1999. Agency, entrepreneurs, and institutional change. The role of strategic choice and institutionalized practices in organizations. Organization Studies, 20: 777-799.

[3] Budeanu, A. 2005. Impacts and responsibilities for sustainable tourism: a tour operator's perspective. Journal of Cleaner Production, 13: 89-97.

[4] CBS. 2004. Bedrijven naar aantal werknemers en economische activiteit. 63301 Reisorganisatiebedrijven. Heerlen: Centraal Bureau voor de Statistiek.

[5] Coughlan, R. 2001. An analysis of professional codes of ethics in the hospitality industry. International Journal of Hospitality Management, 20: 147-162.

[6] de Bakker, F.G.A. 2001. Product-oriented environmental management: lessons from Total Quality Management. Journal of Industrial Ecology, 5(2): 55-69. 
[7] DiMaggio, P.J. 1988. Interest and agency in institutional theory. In L.G. Zucker (Ed.), Institutional patterns and organizations. Culture and environment: 3-21. Cambridge, Ma: Ballinger.

[8] Font, X. 2002. Environmental certification in tourism and hospitality: progress, process and prospects. Tourism Management, 23: 197-205.

[9] Font, X., \& Cochrane, J. 2005. Integrating sustainability into business. A management guide for responsible tour operations: UNEP/DTIE: Paris.

[10] Greenwood, R., Suddaby, R., \& Hinings, C.R. 2002. Theorizing change: the role of professional associations in the transformation of institutionalized fields. Academy of Management Journal, 45: 58-80.

[11] Lawrence, T.B., Winn, M.I., \& Jennings, P.D. 2001. The temporal dynamics of institutionalization. Academy of Management Review, 26: 624-644.

[12] Maguire, S., Hardy, C., \& Lawrence, T. B. 2004. Institutional entrepreneurship in emerging fields: HIV/AIDS treatment advocacy in Canada. Academy of Management Journal, 47: 657-679.

[13] Miller, G. 2001. Corporate responsibility in the UK tourism industry, Tourism Management, 22: 589-598.

[14] NBTC, KHN, RECRON, HISWA, ANVR, \& Stichting Recreatie. 2004. Kerncijfers toerisme \& recreatie. Editie 2004. Leidschendam: Nederlands Bureau voor Toerisme \& Congressen.

[15] Rivera, J. 2002. Assessing a voluntary environmental initiative in the developing world: The Costa Rican Certification for Sustainable Tourism. Policy Sciences, 35: 333-360.

[16] Rivera, J., \& de Leon, P. 2004. Is greener whiter? Voluntary environmental performance of western ski areas. Policy Studies Journal, 32: 417-437.

[17] Scott, W.R. 1987. The adolescence of institutional theory. Administrative Science Quarterly, 32: 493-511.

[18] Tepelus, C.M. 2005. Aiming for sustainability in the tour operating business. Journal of Cleaner Production, 13: 99-107.

[19] Todd, S.E., \& Williams, P.W. 1996. From white to green: a proposed environmental management system framework for ski areas. Journal of Sustainable Tourism, 4: 147-173.

[20] Tyler, D., \& Dinan, C. 2001. The role of interested groups in England's emerging tourism policy network. Current Issues in Tourism, 4: 210-252.

[21] van der Duim, R., \& van Marwijk, R. forthcoming. The implementation of an environmental management system for Dutch tour operators: An actornetwork perspective. Journal of Sustainable Tourism.

[22] van Marwijk, R., \& van der Duim, R. 2004. Met vallen en opstaan: de invoering van PMZ bij Nederlandse touroperators. Vrijetijdstudies, 22(4): 21-32.

[23] WTO/OMT. 2002. Voluntary initiatives for sustainable tourism. Madrid: World Tourism Organization.

[24] Yin, R. K. 2003. Case study research. Design and methods. $3^{\text {rd }}$ edition. Thousand Oaks: Sage. 